\title{
Students' teacher Utterances in Opening and Closing an ESP class
}

\author{
Rindang Widiningrum ${ }^{1}$, Djatmika ${ }^{2}$, Joko Nurkamto ${ }^{3}$, Diah Kristina ${ }^{4}$ \\ \{rindangwidiningrum@student.uns.ac.id ${ }^{1}$,djatmika@staff.uns.ac.id², jokonurkamto@staff.uns.ac.id ${ }^{3}$ \} \\ UNS, Solo ${ }^{1}$, UNS, Solo² ${ }^{2}$ UNS, Solo ${ }^{3}$
}

\begin{abstract}
This study aims to explore the utterances that the students' teacher used in opening and closing a class. The participants of the study were 6 students' teacher who did their Teaching Practicum by teaching English for Hotel Staff. The method used here were observation and students' teacher reflection. So, based on Richards and Lockhart (2007) and also Hughes (2008), the result showed that not all of class routines in general classes appeared in the ESP class. In opening the lesson most of the time the students' teacher giving motivation, while in closing, they do review. Furthermore, in opening the class, utterances that showed entering the classroom, taking register and dealing with lateness were not found. The utterances in closing the lesson for checking the time, setting homework and clearing the class were not found. By seeing the result, hopefully the nature of ESP class can be revealed.
\end{abstract}

Keywords: students' teacher, opening, closing, ESP.

\section{Introduction}

In doing the Teaching Practicum, students' teacher needs sufficient provisions to teach in class. Besides mastery of learning methods, student teacher also needs to have good communication strategies. Lack of knowledge about that can result in communication failures which have an impact on the smooth running of activities in the classroom.

The teacher's role in the teaching and learning process is still dominant (Brown, 2001). Teachers are expected to be role models who can provide understanding to students and provide clear directions and instructions to students. In an era where the emphasis is on students' centered, teachers still have a big role in the teaching and learning process. Furthermore, in this revolution industry 4.0 era, where the online learning is widely used, the teacher's role is still needed.

In Hughes et.al. (2008), class routines are divided into three parts, namely: the beginning of the lesson, running the lesson, and ending the lesson. At each stage, there are utterances that are usually spoken by the teacher. In the beginning of the lesson, the utterances are grouped into: entering the classroom, everyday greetings, meeting a new class, taking register, dealing with lateness, and getting down to work. In running the lesson, there are starting something new, making things clear, sequencing activities, checking progress, and stopping. The last part is ending the lesson, which can be grouped into: checking the time, setting homework, stopping work, making announcements, saying goodbye, and clearing the class.

Meanwhile, according to Richards and Lockhart (2007), in opening lessons, there are several activities that must be present. The first reviews the previous lesson. Here, the teacher 
can review previous lessons and also show the relationship between the current lesson and the previous lesson. The second states the topic. At this point, what the teacher can do is look back at the lesson and state the activities that students will learn. The third states objective. In stating objectives, the teacher must state the information or skills that students will learn and also describe what they are expected to do in the lesson. The next point is stating benefits. Teachers can describe the relationship between lessons or activities when the lesson takes place with real world needs. In addition, the teacher can also describe the relationship between the day's lesson and future assignments or tests. The last one in the opening is providing motivation, where the teacher can do something to capture interest and motivate students.

In closing the lesson, there are three points that must be considered by the teacher. It provides summaries, reviews, and links to future lessons (Richards and Lockhart, 2007). In summarizing, the teacher must review what has been discussed in the lesson. Furthermore, in reviewing, the teacher can review the important points of the lesson and link the lesson to the lesson objectives. In addition, teachers can also show the relationship between lessons and previous lessons and show how lessons related to the real-world needs of students.

Research in the educational domain has been carried out by many experts. The first is research on textbooks related to pragmatic abilities and speech acts (Delen \& Tavil, 2010; Ekin, 2013; Afzali and Rezapoorian, 2014). In these studies, the researchers looked at and evaluated the existence of pragmatic aspects, in this case the perspective of speech acts in English textbooks for non-native speakers. Research on teacher-student interactions in the educational domain has also been widely carried out, such as giving and receiving suggestions (Henricson \& Nelson, 2017), teacher interruptions (Yataganbaba \& Yildirim, 2016), and asking strategies (Tan \& Farashaiya, 2012; Tabatabaei \& Samiee, 2013; Daskalovska et al, 2016; Karatepe, 2016). In the field of ESP, there is research conducted by Aylazyan and Obdalova (2014) to obtain the implications of ESP training for the development of the professional competence of training participants.

The research question for this paper is what are the utterances that the students' teacher used in opening and closing the class. The aim of this paper is to explore the utterances of the students' teacher and group it first into Richards and Lockhart's classification. After that, finding the utterances will be grouped based on Hughes' classification.

Theoretically, the results of this study can contribute to the development of types of utterances at each stage of learning that occurs in English classes for special purposes. For student teacher, the results of this study can be a reference for them when they have to provide English language training for specific purposes.

\section{Methodology}

According to Creswell (2003, p. 181), "Qualitative research takes a place in the natural setting." One of the reasons this research can be categorized as qualitative research is because the research data is taken from the place where the participants are, namely in this study is the place where English language training is held.

Participants in this study were 6 students' teacher who have done their Teaching Practicum by teaching English for Hotel Staff. The staff were from some departments in 2 different hotels in a small city in Central Java. The students' teacher has met the requirements to practice teaching. The teaching practice chosen was teaching English for special purposes. These participants have gone through various stages, namely conducting need analysis, creating course 
designs, creating materials and finally teaching. The teaching practice was done face to face in the hotel.

In this study, the researcher conducted several ways to collect data, namely: observation and document analysis. Observation is made to find out what happened in the field. At the time of making observations, the researcher recorded and also took notes. Observations were made several times, but in this study, the observations used as data were 12 times, in which each students' teacher was observed twice. Furthermore, the students' teacher self-reflection will also be used to enrich the data.

The data will be analyzed using an ethnographic analysis model (Spradley, 1980), namely domain analysis, taxonomic analysis, component analysis, and cultural theme analysis. After transcribing, the utterances will be grouped based on Richards and Lockhart's theory. Then, the researcher will find some utterances that suitable with Hughes's classification.

\section{Finding and Discussion}

On the following paragraphs, the finding will be presented and discussed. It will be started by grouping the opening and closing section into Richards and Lockharts (2007), then the language routine based on Hughes' classification (2008) will be revealed.

Below is the first table of utterances in the opening that were grouped based on Richards and Lockharts (2007) activities.

Table 1. Utterances in Opening

\begin{tabular}{ll}
\hline Grouping Utterances in the activities of: & Percentage \\
\hline Greeting & $13,43 \%$ \\
Reviewing previous lesson & $14,43 \%$ \\
Stating the topic & $13,93 \%$ \\
Stating the Objective & $1,49 \%$ \\
Stating the benefit & $27,86 \%$ \\
Giving Motivation & $28,86 \%$ \\
\hline
\end{tabular}

From the above table, students' teacher utterances can be grouped into giving motivation $28,86 \%$, stating the benefit $27,86 \%$, reviewing previous lesson $14,43 \%$, stating the topic $13,93 \%$, greeting $13,43 \%$, and stating the objective $1,49 \%$.

Those figures showed that students' teacher spend most of the time to give motivation and state the benefit. One of the activities of giving motivation here is watching a short movie before the lesson began. The situation is in the opening, from one of the classes, P5 asked the staff to watch a short movie.

Extract (Hs18B - 38B)

P5 : "We will see a video.... Actually tells about ya. Sport mental and also Motivation. ... Everyone has their potention skill. In your division you have your own desk job description and then.... Memanfaatkan potensi yang ada dan selalu semangat (Using all the existing potencies and always be enthusiastic). Never give up." 
Here, P5 ask the staff to never give up to learn and use all the potencies that they have. Furthermore, from the students' teacher individual reflections, some of them wrote that the staff lacks of motivation in joining the English training. Since the material that was taught by students' teacher was the result of need analysis, it should be matched with what the staffs need. Actually, English for Specific Purposes (ESP) was born because of three things, namely the need for a new world, a revolution in linguistics and a learner focus (Hutchinson and Waters, 1987). The assumption at that time was that the clearer relationship between English training and the needs of learners would increase the motivation of learners so that the learning process would be better and faster.

Students' Teacher Reflection:

P5: ... some of the staffs thought that English is not really used in their daily activity, so it made them demotivated.

P4: ... some of the guests ... were not English native speakers.

As stated by P4 and P5 in their reflection that some staffs lack of motivation to learn English, because in doing the job, the staff rarely used English. Moreover, they stated that not all of the guests were native speakers. The situation made the staffs lack of motivation, that is why the students' teacher need to motivate the staffs.

After discussing the opening section, below is the finding in closing section.

Table 2. Utterances in Closing

\begin{tabular}{ll}
\hline Grouping Utterances in the activities of: & Percentage \\
\hline Summarizing & $6,58 \%$ \\
Reviewing & $46,05 \%$ \\
Making links to a forthcoming lesson & $27,63 \%$ \\
Farewell & $19,74 \%$ \\
\hline
\end{tabular}

Based on Table 2, most of the time, the students' teacher did review which was $46,05 \%$ compared to other activities in closing the lesson. After that, the students' teacher utterances can be grouped into making links to a forthcoming lesson $27,63 \%$, farewell $19,74 \%$, and summarizing $6,58 \%$.

Based on the researcher's observation, the participants usually came and go, because of their job. For example, if there were 5 staffs, 2 of them were on duty, so they have to come and go when there were guests need their help. It happened almost in every meeting.

Below is taken from students' teacher reflection:

P3: ... I could not oblige them to come to the class due to their working circumstances.

P4: However, ... there are two students left only.

From the reflection, it can be concluded that the students' teacher can not oblige the staff to join the class fully, because of the duty of the staff. According to Brown (2007), there are some points that teacher need to consider when teaching adult learners. One of them is do not discipline adult learners in the same way that you are used with children. Besides that, Y also mentioned in her reflection, that there were times that there were two staffs left, out of five at the end of the class. From the observation and reflection, it can be concluded that reviewing is needed to be done in closing the lesson, because of the situation in which the staffs can not stay 
fully in class. By doing the review, it is hoped that all the staffs can get the points which were being learned that day.

In the following paragraphs, the utterances based on Hughes (2008) will be discussed.

The following are some of the utterances that fall within the domain of opening lessons. The first sub domain of opening the lesson is greetings. The situation is when P3 will start teaching which at that time is the beginning of the meeting.

Extract F1

P3 : “Good morning everyone."

The English language training provided by P3 is conducted in the morning starting at 10 am, so the greeting is "Good morning."

The next sub domain discussed is the first meeting with a new class. The situation was during the first meeting between $\mathrm{P} 3$ and the participants.

Extract E1-3

P3 : "We are here to teach and to help you to learn English. So, hopefully you will learn something from our lesson."

The above utterances occurred during the first meeting between P3, who at that time was paired with P6. At that time P3 opened the class by saying that they, namely P3 and P6 would teach, and hoped that the hotel staff could learn something from the lesson.

Here is one example of the sub domains of getting down to work. The situation is when P3 finishes greeting, $\mathrm{P} 3$ informs the hotel staff that it is time for lessons to start.

Extract F2

P3 : "Since it's already 10 past 10 , so we will start our lesson today."

The English training should have started at 10 sharps, but because not many participants were present, it started at 10.10. Here, the student's teacher informed the staff, that the lesson was getting started.

In opening the lesson, there are some language routine that cannot be found. Those are entering the classroom, taking register, and dealing with lateness. In every meeting, students' teacher was already in the room and usually the participants will enter the room by themselves. For taking the register, usually during the lesson or at the end of the lesson, the students' teacher asked the participants to sign the attendance list in a piece of paper. That is why, there are no utterances that signals taking the register. As stated above by Brown (2007), that teacher cannot treat adult learners as children, so the students' teacher never deals with the staffs' lateness. Since the staffs are older than the students' teacher and usually, they were late because of the duty.

In closing the lesson, there are no utterances in the categories of checking time, giving homework and clearing the class. The students' teacher never gave homework. Due to the workload of the staffs, usually, students' teacher never gave homework to the staff. The activities and assignment were done during the training. Without clearing the class, usually after the farewell, the staffs will leave the room. 
Here are some examples of utterances from students' teacher from each sub domain in ending the lesson. The first sub domain is stopping work. The situation was nearing the end of the meeting.

Extract B249

P4 : "Today, we have material about reservation and check in."

To end the lesson, $\mathrm{P} 4$ reminds the participants about the topic of the day, namely reservation and check-in. P4 said this utterance after the staffs finished doing the last activity. So, by saying that, it means that the activity for that day is finished.

The next sub domain is making announcements. The situation is at the end of the lesson and $\mathrm{P} 2$ gives an announcement about the activities at the next meeting.

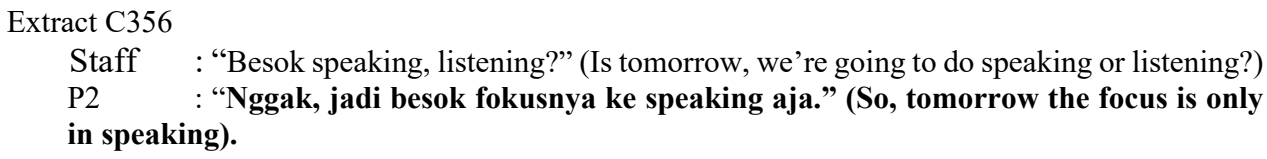

When a participant asked about the topic of the test for the next meeting, whether the two materials were speaking and listening or just one, $\mathrm{P} 2$ answered that the focus was one, namely speaking. This was considered as giving announcement for the next meeting. The announcement was related to the test that the staff were going to take in the next meeting.

The last sub domain in the ending lessons is farewell. The situation is at the end of lesson P4 saying goodbye.

Extract B254

P4 : "See you next meeting."

For the farewell, P4 said "see you at the next meeting", with the hope that the participants. will come again at the next meeting. This utterance is also a signal to the class that it was dismissed and the staffs may leave the room, because the class was over. So here, the students' teacher didn't have to say: "You can go now or Take all your things with you" (Hughes et. al., 2008) to ask the staffs to leave the class.

From the data and the discussion, it can be seen that class routine in teaching English for Specific purposes are different with general classes.There are various factors that affected. In this context, the learners are more mature than the students' teacher, furthermore, they have worked as hotel staff. So, that is why some class routines, such as dealing with lateness and giving homework, were not exist in this ESP class.

\section{Conclusion}

The aim of the research is to explore the utterances and grouped them based on the activities in opening and closing the lesson. Furthermore, the language routine based on Hughes's classification were also be found. 
In opening the lesson, the students' teachers do the following things: greet, review previous lesson, state the topic, state the objective, state the benefit, and give motivation. There is some language routine that signals to: everyday greetings, meeting a new class and getting down to work, while entering the classroom, taking register and dealing with lateness were not found.

In closing the class, there are summarizing, reviewing, making links to a forthcoming lesson, and farewell. There are some utterances as language routine that signals: stopping work, making announcement and saying goodbye, while checking the time, setting homework and clearing the class were not found in this study.

There are similarities between ESP class and other classroom: there are activities like greeting, review previous lesson, state the topic, objective, benefit and give motivation in opening. While in closing, there are: summarizing, reviewing, making links to a forthcoming lesson and farewell.

The differences are in the language routine. In ESP class, there were no entering the classroom, taking register, and dealing with lateness in opening. While in closing there were no checking the time, setting homework and clearing the class.

This study has its own limitation. For further study, the participants can be added in number and also the interview can also be done to deepen the data. It will be interesting also to study about the pattern of communication that happened in the teaching and learning process.

\section{References}

[1] Afzali, Katayoon \& Davood Rezapoorian. Pragmatic Aspects of English for tourism coursebooks and ESL learners pragmatic Needs: A speech Act Theory. Procedia-Social and Behavioral Sciences. 2014; 98: 52-59.

[2] Aylazyan, Yelena P \& Olga A. Yobdalova. ESP Adult course Implications for Professional Competence Development. Procedia-Social and Behavioral Sciences. 2014; 154: 381-385.

[3] Brown, Douglas H. Teaching by Principles: An Interactive Approach to Language Pedagogy, $2^{\text {nd }}$ Edition. New York: Addison Wesley Longman, Inc.; 2001.

[4] Creswell, John W. Research Design: Qualitative, Quantitative, and Mixed Methods Approaches. California: SAGE Publications, Inc.: 2003

[5] Daskalovska, Nina, Biljana Ivanovska, Marija Kusevska \& Tatjana Ulanska. The Use of Request Strategies by EFL Learners. Procedia-Social and Behavioral Sciences. 2016; 232: p. 55-61.

[6] Delen, Busra \& Zekiye Muge Tavil. Evaluation of four coursebooks in terms of three speech acts: requests, refusals, and complaints. Procedia-Social and Behavioral Sciences. 2010; 9: 692-697.

[7] Ekin, Mehzudil Tugba Yildiz. Do current EFL coursebooks work for the development of L2 pragmatic competence? The case of suggestion. Procedia-Social and Behavioral Sciences. 2013; 93: $1306-1310$.

[8] Henncson, Sofie \& Marie Nelson. Giving and Receiving advice in higher education; Comparing Sweden-Swedish and Finland-Swedish supervision meetings. Journal of Pragmatics. 2017; 109 : p. $105-120$.

[9] Hughes, Glyn, Josephine Moate \& Tiina Raatikainen. Practical Classroom English. Oxford: Oxford University Press; 2008. 
[10] Hutchinson, T. \& Waters, A. English for Specific Purposes. Cambridge: Cambridge University Press; 1987.

[11] Karatepe, Cigdem. Indirectness in Requests in Complaint Letters to the Higher Institution by Turkish EFL Students. Procedia-Social and Behavioral Sciences 2016; 232: p. 354-361.

[12] Richards, Jack C, \& Lockharts. Reflective Teaching in Second Language Classrooms. Cambridge: Cambridge University Press; 2007.

[13] Silverman, David. Doing Qualitative Research: A Practical Handbook. London: Sage Publications Ltd.; 2000.

[14] Spradley, James P. The Ethnographic Interview. Orlando: Harcourt Brace Jovanovich College Publishers; 1979.

[15] Tabatabaei, Omid, \& Zeinab Samiee. Transfer of requestive speech act from L1 to L2 in Iranian EFL Learners. Procedia-Social and Behavioral Sciences. 2013; 70: p. 239-244.

[16] Tan, Kim Hua \& Atieh Farashaiya. Utilizing formulaic request strategies in an ESL classroom. Procedia-Social and Behavioral Sciences 2012; 59: 42-46.

[17] Yataganbaba, Esra \& Rana Yildirim. Teacher Interruptions and Limited Wait Time in EFL Young Learner Classrooms. Procedia-Social and Behavioral Sciences. 2016; 232: p. 689-695.

[18] Yin, Robert K. Qualitative Research from start to finish. New York: The Guilford Press; 2011. 